Sains Malaysiana 50(4)(2021): 1047-1056

http://doi.org/10.17576/jsm-2021-5004-15

\title{
Risk Associated with Immediate Implant at Mandibular Canine and Premolars: A Cone Beam Computed Tomography (CBCT) Study
}

(Risiko Berkaitan dengan Implan Segera pada Gigi Taring dan Geraham: Kajian Tomografi Berkomputer Pancaran Kon)

\author{
KIRTHiga RAMESWARAN, AMINAH MOHD SHARIFF \& DANIEL LIM*
}

\section{ABSTRACT}

With the evolution of implant dentistry, immediate implantation remains a challenge especially in achieving a good primary stability with avoidance of complications such as nerve injuries and lingual perforations. This study was aimed to determine the risks of nerve injury and lingual perforation following virtual implant placement at mandibular canines, mandibular first premolars and mandibular second premolars using cone beam computed tomography (CBCT) scans. From the total of 771 CBCT scans screened, 100 CBCT scans were included. Measurements were made based on the cross-section of the study teeth, that were mandibular canine, first premolar and second premolar, to obtain the distance between root apex and nerve canal as well as risk of nerve injury. A virtual implant was then placed at each site to assess the risk of lingual perforation. Generally, the distance between root apex and nerve was less than 6 mm and the highest risk of nerve injury was observed at second premolar (79.6\%) followed by first premolar (45.3\%) and canine (23.4\%). Risk of lingual perforation following immediate implant placement was between 0.7-1.5\%. The risk of nerve injury was considerably high due to insufficient root apex to nerve canal distance while the risk of lingual perforation was low.

Keywords: Complications; cone beam computed tomography; dental implant; mandible

\section{ABSTRAK}

Dengan perkembangan dalam implan pergigian, pengimplanan serta-merta masih merupakan satu cabaran terutamanya dalam mencapai kestabilan primer yang baik di samping mengelakkan komplikasi seperti kecederaan saraf dan perforasi lingual. Penyelidikan ini adalah bertujuan untuk menentukan risiko kecederaan saraf dan perforasi lingual berikutan perletakan implan maya pada gigi taring, gigi geraham kecil pertama dan kedua rahang bawah dengan menggunakan imbasan tomografi berkomputer pancaran kon (CBCT). Daripada 771 imbasan CBCT yang disaring, 100 imbasan CBCT telah dimasukkan dalam penyelidikan ini. Bagi memperoleh jarak antara apeks akar gigi dan kanal saraf, ukuran telah dilakukan pada keratan rentas imbasan CBCT gigi taring, geraham kecil pertama dan kedua rahang bawah. Satu implan maya kemudiannya diletakkan pada kedudukan setiap gigi tersebut untuk menilai risiko perforasi lingual. Secara umumnya, jarak di antara apeks akar dan kanal saraf adalah kurang daripada 6 mm dan risiko kecederaan saraf adalah paling tinggi pada kedudukan geraham kecil kedua (79.6\%) diikuti geraham kecil pertama (45.3\%) dan geraham kecil kedua (23.4\%). Risiko perforasi lingual berikutan implan serta-merta adalah antara $0.7-1.5 \%$. Risiko kecederaan saraf adalah agak tinggi memandangkan kekurangan jarak antara apeks akar gigi dan kanal akar, manakala risiko perforasi lingual adalah rendah.

Kata kunci: Implan pergigian; komplikasi; rahang bawah; tomografi berkomputer pancaran kon

\section{INTRODUCTION}

Implant treatment is evolving to become more simplified and widely used in a variety of prosthodontic treatments such as single tooth replacement, multiple teeth replacement, support for complete arch fixed dental prostheses, and retention for removable complete and partial overdentures. Chen and Buser (2009) classified timing of implant placement into four types. Placement of implant into a fresh extraction socket is classified as Type 1 or immediate implant placement. When implant is inserted between 4 and 8 weeks after extraction during 
which soft tissue has healed, it is classified as Type 2. Type 3 classification is defined as insertion of implant between 12 and 16 weeks when extraction site has shown significant soft tissue and bone healing. Placement of implant after 6 months in a fully healed socket is termed as Type 4 or late placement (Chen \& Buser 2009).

Despite claims that immediate implant offers several benefits such as reduced treatment time, preservation of bone and higher patient comfort and satisfaction, this procedure is not without any setbacks. One of the limitations is the need for adequate bone beyond the root apex to achieve good primary stability. To achieve a successful immediate implantation, an implant must engage 3 to $5 \mathrm{~mm}$ of bone beyond the root apex (SchwartzArad \& Chaushu 1997). Because of this, immediate implantation carries the risk of injury to structures located apical to the root apex such as the Schneiderian membrane and inferior alveolar nerve. Froum et al. (2011) found that the risk of injury to inferior alveolar nerve was high for mandibular second premolars, first molars, and second molars (Froum et al. 2011). To make immediate implantation more challenging, an additional minimum distance of $2 \mathrm{~mm}$ between implant and nerve is necessary to safely avoid nerve injury (Greenstein \& Tarnow 2006).

Although mental nerve is usually located either apical to second premolar or between first and second premolar, placing implant mesial to second premolar does not completely avoid neurosensory complication due to the presence of anterior loop (Chen et al. 2015). Juan del et al. (2016) reported the presence of anterior loop in more than $90 \%$ of their samples. In some samples, the loop extended as far as to the mandibular canine. Besides branching off as mental nerve, inferior alveolar nerve continues its course anteriorly as incisive nerve. With an average length of $10 \mathrm{~mm}$, incisive nerve may travel till the midline in $18 \%$ of the population (Juodzbalys et al. 2010). Therefore, placing implants anterior to the mental foramen may not be as safe as it was thought.

To date, studies on the risk of inferior alveolar nerve injury and lingual perforation during immediate implant placement only considered second premolars, first molars, and second molars. No studies had yet included the first premolar and canine. Therefore, our study aimed to determine the risk of nerve injury and lingual perforation following virtual implant placement using cone beam computed tomography (CBCT) at mandibular canines, mandibular first premolars and mandibular second premolars.

\section{MATERIALS AND METHODS \\ SAMPLE COLLECTION}

This study was carried out at the Faculty of Dentistry, University of Malaya with the approval from the Ethical Committee of Faculty of Dentistry, University of Malaya (DF OS1807/0019(U)). Seven hundred and seventyone (771) cone beam computed tomography (CBCT) scans taken with i-CAT imaging system (Imaging Sciences International Inc, Hatfield, USA), at the Oral and Maxillofacial Radiology Unit, Faculty of Dentistry, University of Malaya were assessed and 100 CBCT scans that fulfilled the inclusion and exclusion criteria were selected. The imaging parameters were set at $120 \mathrm{kVp}$, 3-7 $\mathrm{mA}$, scan time $20 \mathrm{~s}$ and resolution at $0.3 \mathrm{~mm}$ voxel size. All the scans were retrospectively selected from the $\mathrm{CBCT}$ database and were not specifically acquired for this project.

CBCT scans were selected if at least either side (left or right) or both sides of the jaws fulfilled all the criteria below.

Inclusion criteria includes: Fully erupted mandibular permanent canines, first premolars and second premolars; Each study tooth had fully formed apex, Outline of the inferior alveolar nerve canal could be easily identified, Study teeth were in normal position (an imaginary line connecting the cusp tip of canines, first and second premolars are generally smooth), and the presence of opposing maxillary tooth (as a guide in implant positioning).

Exclusion criteria includes: Presence of pathology or fracture of mandible, presence of plates and screws, implants or grafted alveolar ridge at the area of study, missing of either one of the study teeth (mandibular canine, first premolar or second premolar), and incomplete or unclear images due to scattering or other reasons.

MEASUREMENT OF ROOT APEX TO NERVE CANAL DISTANCE AND RISK OF NERVE INJURY

Measurements and evaluations of the selected images were done using Blue Sky Plan version 4.2.5 software. Thickness of each slice of images was set at $1.0 \mathrm{~mm}$. The cross section slice closest to the center of the study tooth was selected for subsequent measurements and virtual implant placement. All measurements were done independently by two investigators, following which the average value the measurements were recorded to ensure data reliability. Any disagreements in the interpretation and evaluation of the images were discussed between the two investigators until a consensus was reached. 
First, the nerve canals were identified and marked in the cross-section image of the study teeth. In areas with anterior loops, the more superiorly located nerve canal was marked. Following that, a horizontal tangential line was drawn over the root tip of the study tooth and another similar line drawn over the superior border of the nerve canal. Distance from the root apex to the nerve canal (A) was measured as the distance between these two horizontal lines (Figure 1). A minimum distance of $6 \mathrm{~mm}(\geq 6 \mathrm{~mm})$ was considered adequate for immediate implant placement, taking into consideration $4 \mathrm{~mm}$ of bone apically were needed for immediate implant to achieve considerably good stability (Lazzara 1989) and an additional $2 \mathrm{~mm}$ as safety zone from the nerve. If the distance was less than $6 \mathrm{~mm}(<6 \mathrm{~mm})$, immediate implant placement was considered as high risk for nerve injury.

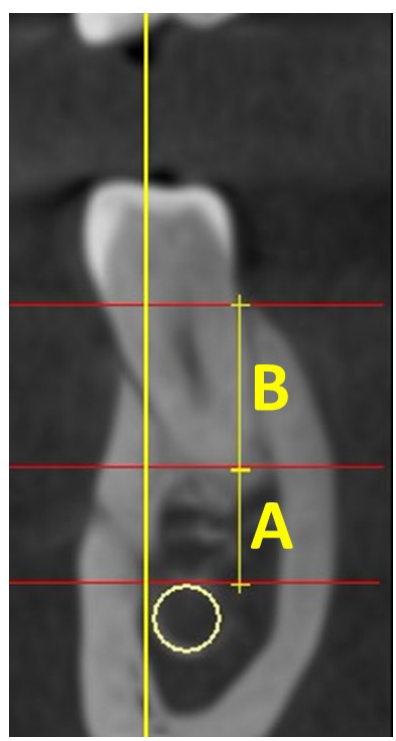

FIGURE 1. The nerve canal was first identified. Horizontal lines were drawn at the root tip of study tooth, superior border of nerve canal and alveolar crest of lingual bone

ASSESSMENT OF CROSS SECTION ALVEOLAR BONE MORPHOLOGY

Cross section alveolar bone morphology of the study teeth was observed and classified into 4 types based on modified Chan et al.'s classification (Chan et al. 2011b). The types of morphology and its definition are shown in Figure 2.
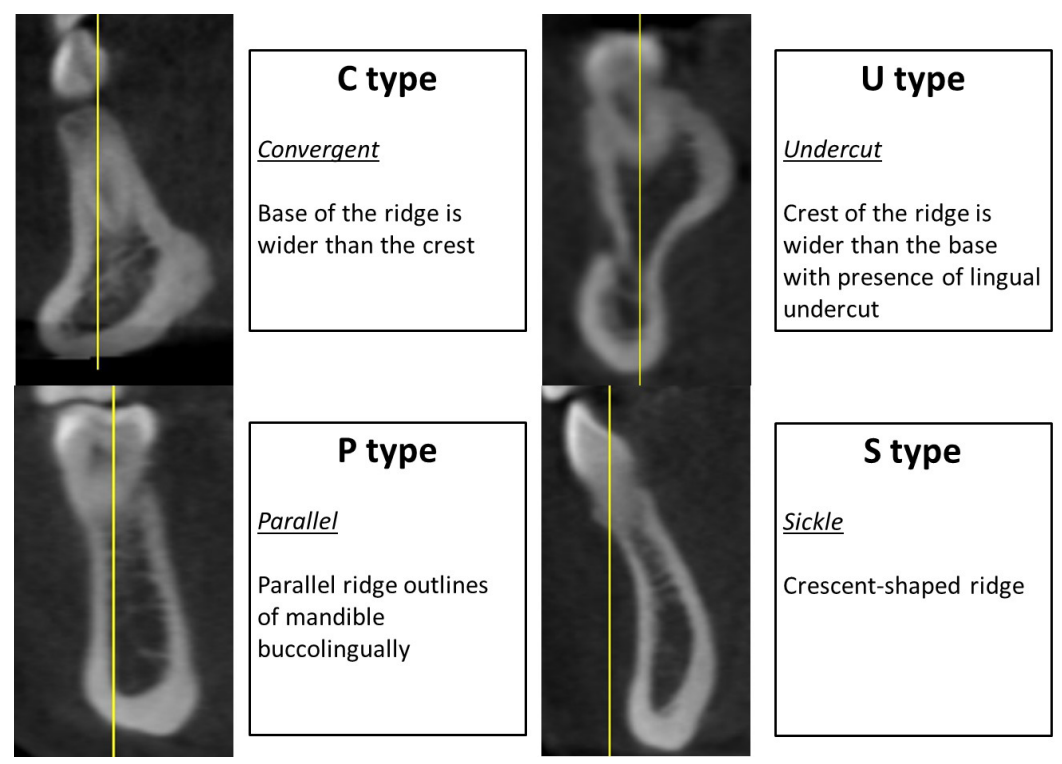

FIGURE 2. Types of alveolar bone morphology (modification of Chan et al. (2011b)) 


\section{VIRTUAL IMPLANT PLACEMENT AND LINGUAL PLATE} PERFORATION

Prior to evaluating lingual plate perforation, implant length was determined. The ideal length of implants was decided by adding $4 \mathrm{~mm}$ to the distance between tangential horizontal line over the root tip and tangential horizontal line over the alveolar crest of lingual bone (B) (Figure 1). Upon confirmation of the length, parallel implants of 3.5 and $4.0 \mathrm{~mm}$ diameter were virtually placed at mandibular canines. To ensure reproducibility and simulate ideal screw hole position, implants were placed with the centre of the implants in line with cingulum of the mandibular canines (buccolingual) and perpendicular to the mandibular occlusal plane (mesiodistal). The same mesiodistal angulation (Figure 3(a)) was used for mandibular first and second premolars but with the centre of implants opposing functional cusps of maxillary teeth (buccolingual) (Figure 3(b)). Parallel implants of 4.0, 4.5 , and $5.0 \mathrm{~mm}$ diameter were used in premolars areas. Position of the virtual implants was verified in three dimensional (3D) views (Figure 3(c)). Lingual plate perforation was defined as the extrusion of the virtual implants from the lingual cortical bone.

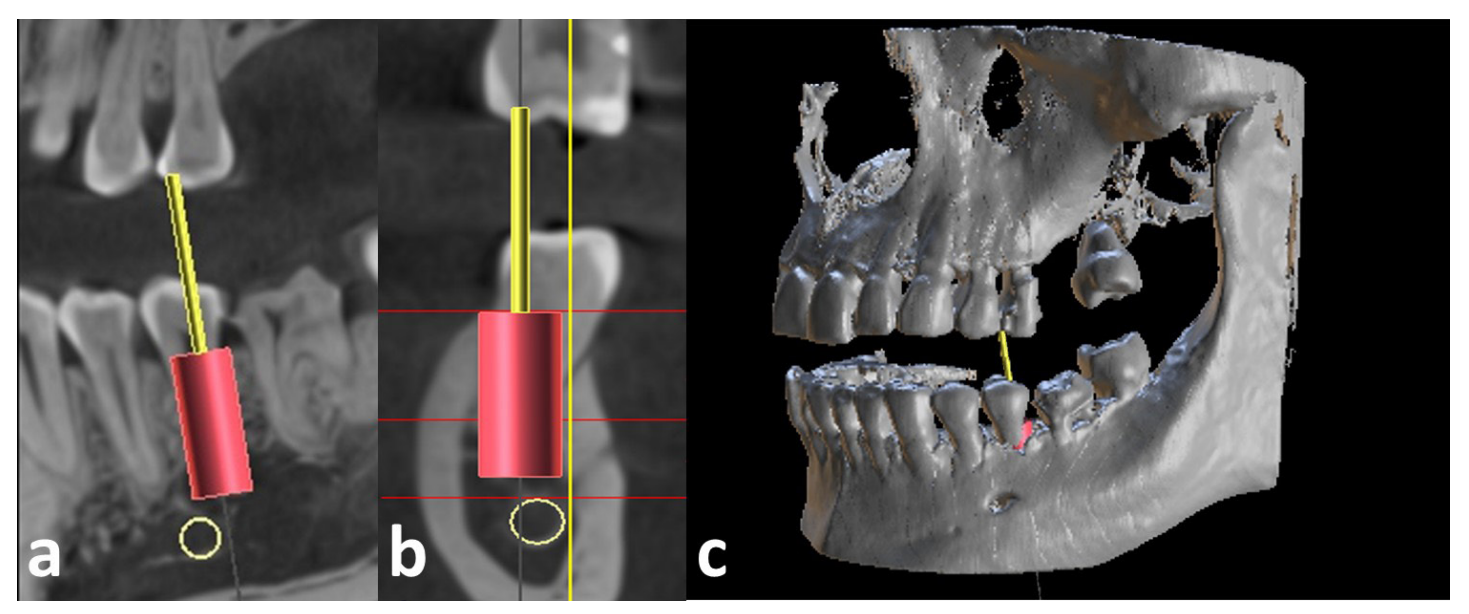

FIGURE 3. (a) Mesiodistal positioning of implant, (b) Buccolingual positioning of implant, and (c) Implant position in 3 dimensions (3D)

\section{DATA ANALYSIS}

Data obtained were analyzed using Statistical Package for Social Sciences (SPSS) software version 25.0. Descriptive analysis data including mean, frequency and percentage were computed. Difference in mean values between left and right side of mandible were analyzed using T-test and significant value was set at $\mathrm{P}<0.05$.

\section{RESULTS}

A total of 100 CBCT scans were included in this study from the $771 \mathrm{CBCT}$ scans assessed. These scans belonged to 52 males and 48 females. Of these scans, $48 \%$ were of Malay ethnicity, 31\% Chinese, $16 \%$ Indian and 5\% of others ethnicity. In 37 CBCT scans, both sides of the mandible fulfilled the inclusion criteria while only one side of the mandible can be included in the remaining 63 CBCT scans. A total of 137 mandibular canines, mandibular first premolars and mandibular second premolars, respectively, were included in this study. Of this number, 71 samples were from the left side of mandible and 66 samples were from the right side. Mean age of the patients included in this study was 31.9 years old. The mean inter rater reliability was $92.35 \%$.

\section{ROOT APEX TO NERVE CANAL DISTANCE AND RISK OF NERVE INJURY}

Nerve canals were present apically at $28.5 \%(n=39)$ of mandibular canines, $69 \%(n=95)$ of mandibular first 
premolars and $100 \%(\mathrm{n}=137)$ of mandibular second premolars. The distance from root apices of the respective teeth to nerve canal are shown in Table 1. It was observed that the measurements at the right side of mandible were generally less than that of the left side. However, the difference was not significant. The mean root apex to nerve canal distance increased from canine to first premolar but reduced to almost similar distance as canine at second premolar.

By defining the minimal safe distance of $6 \mathrm{~mm}$ from the root apices to nerve canals, second premolar $(n=109$, $79.6 \%$ ) recorded as the site with the highest risk of nerve injury followed by first premolar $(\mathrm{n}=62,45.3 \%)$ and canine ( $\mathrm{n}=32,23.4 \%)$. In general, the mean root apex to nerve canal was less than $6 \mathrm{~mm}$ for all the three teeth.

TABLE 1. Root apex to nerve canal distance and risk of nerve injury

\begin{tabular}{|c|c|c|c|c|c|}
\hline Tooth & Mean root apex & hal distance $\pm \mathrm{SD}$ & $\mathrm{p}$ value* & $\begin{array}{l}\text { No. of tooth with } \\
\text { presence of nerve } \\
\text { apically (n) }\end{array}$ & $\begin{array}{l}\text { Risk of nerve injury } \\
\text { from immediate } \\
\text { implantation }\end{array}$ \\
\hline \multirow[t]{3}{*}{ Canine } & Left & $4.15 \pm 2.32$ & \multirow{3}{*}{0.84} & \multirow{3}{*}{39} & \multirow{3}{*}{$23.4 \%$} \\
\hline & Right & $4.07 \pm 2.31$ & & & \\
\hline & Overall & $4.10 \pm 2.28$ & & & \\
\hline \multirow[t]{3}{*}{ First premolar } & Left & $5.19 \pm 2.74$ & \multirow{3}{*}{0.83} & \multirow{3}{*}{95} & \multirow{3}{*}{$45.3 \%$} \\
\hline & Right & $5.06 \pm 2.99$ & & & \\
\hline & Overall & $5.12 \pm 2.86$ & & & \\
\hline \multirow{3}{*}{$\begin{array}{l}\text { Second } \\
\text { premolar }\end{array}$} & Left & $4.55 \pm 2.56$ & \multirow{3}{*}{0.64} & \multirow{3}{*}{137} & \multirow{3}{*}{$79.6 \%$} \\
\hline & Right & $3.90 \pm 2.32$ & & & \\
\hline & Overall & $4.24 \pm 2.46$ & & & \\
\hline
\end{tabular}

\section{CROSS SECTION MORPHOLOGY AND LINGUAL PLATE PERFORATION}

$\mathrm{S}$ type alveolar bone was mainly seen at mandibular canines $(n=106)$ but none at second premolars. In contrast, $\mathrm{U}$ type alveolar bone was mainly observed at second premolar $(\mathrm{n}=21)$ but none at canine. The most commonly observed alveolar bone morphology was $\mathrm{P}$ type $(\mathrm{n}=174)$, followed by $S$ type $(n=132), C$ type $(n=78)$ and $U$ type $(n=27)$. Only one lingual perforation was observed at mandibular canine while three lingual perforations were seen at first and second premolars, respectively. Most lingual perforations occurred at mandibular premolars were associated with $\mathrm{P}$ type alveolar bone morphology. The incidence of different cross section morphology of mandible at study sites and the associated lingual perforations are shown in Table 2.

Besides risk of nerve injury, this study also investigated the risk of lingual plate perforation at the study sites following immediate implant placement.
Placement of immediate implants replacing mandibular canines carried a risk of $0.7 \%$ when $4.0 \mathrm{~mm}$ diameter implants were used. When replacing mandibular first premolars, the risks were 0.7 and $1.5 \%$, respectively, when 4.5 and $5.0 \mathrm{~mm}$ diameter implants were used. A similar risk was observed when 4.5 and $5.0 \mathrm{~mm}$ diameter implants were placed at mandibular second premolars. Generally, the risk of lingual plate perforations increased with implants diameter (Table 2).

The incidence of lingual perforation and high risk of nerve injury following placement of different diameter virtual implants was cross tabulated and is summarized in Table 3. Incidence of both lingual perforation and nerve injury occurring was generally low with only 5 cases $(1.2 \%)$ from the total number of teeth included. Risk of getting both complications simultaneously seems to increase with the diameter and the more posterior position of the implants. 
TABLE 2. Lingual plate perforation with different implant sizes and alveolar ridge morphology

\begin{tabular}{|c|c|c|c|c|c|c|}
\hline & & \multicolumn{5}{|c|}{ Lingual plate perforation } \\
\hline & & \multicolumn{3}{|c|}{ Yes } & \multicolumn{2}{|c|}{ No } \\
\hline & & $\mathrm{n}$ & & $\%$ & $\mathrm{n}$ & $\%$ \\
\hline \multicolumn{7}{|l|}{ Implant sizes } \\
\hline \multirow[t]{2}{*}{ Canine } & $3.5 \mathrm{~mm}$ & & 0 & 0 & 137 & 100.0 \\
\hline & $4.0 \mathrm{~mm}$ & & 1 & 0.7 & 136 & 99.3 \\
\hline \multirow[t]{3}{*}{ First premolar } & $4.0 \mathrm{~mm}$ & & 0 & 0 & 137 & 100.0 \\
\hline & $4.5 \mathrm{~mm}$ & & 1 & 0.7 & 136 & 99.3 \\
\hline & $5.0 \mathrm{~mm}$ & & 2 & 1.5 & 135 & 98.5 \\
\hline \multirow[t]{3}{*}{ Second premolar } & $4.0 \mathrm{~mm}$ & & 0 & 0 & 137 & 0 \\
\hline & $4.5 \mathrm{~mm}$ & & 1 & 0.7 & 136 & 99.3 \\
\hline & $5.0 \mathrm{~mm}$ & & 2 & 1.5 & 135 & 98.5 \\
\hline \multicolumn{7}{|c|}{ Alveolar ridge morphology } \\
\hline \multirow[t]{4}{*}{ Canine } & S type & & 1 & 0.7 & 106 & 77.4 \\
\hline & C type & & 0 & 0 & 18 & 13.1 \\
\hline & P type & & 0 & 0 & 13 & 9.5 \\
\hline & U type & & 0 & 0 & 0 & 0 \\
\hline \multirow[t]{4}{*}{ First premolar } & S type & & 0 & 0 & 26 & 19.0 \\
\hline & C type & & 0 & 0 & 28 & 18.2 \\
\hline & P type & & 3 & 2.2 & 80 & 58.4 \\
\hline & U type & & 0 & 0 & 6 & 4.4 \\
\hline \multirow[t]{4}{*}{ Second premolar } & S type & & 0 & 0 & 0 & 0 \\
\hline & C type & & 0 & 0 & 35 & 25.6 \\
\hline & P type & & 2 & 1.5 & 81 & 59.1 \\
\hline & U type & & 1 & 0.7 & 21 & 15.3 \\
\hline
\end{tabular}

TABLE 3. Incidence lingual perforation and high risk of inferior alveolar nerve injury using different implant diameters

\begin{tabular}{ll}
\hline Lingual perforation and high risk of ID nerve injury & \\
\hline Canine $\varnothing 3.5$ implant & 0 \\
Canine $\varnothing 4.0$ implant & 1 \\
& \\
First Premolar $\varnothing 4.0$ implant & 0 \\
First Premolar $\varnothing 4.5$ implant & 1 \\
First Premolar Ø5.0 implant & 1 \\
& \\
Second Premolar $\varnothing 4.0$ implant & 0 \\
Second Premolar $\varnothing 4.5$ implant & 0 \\
Second Premolar $\varnothing 5.0$ implant & 2 \\
\hline Total & 5 \\
\hline diameter (mm) &
\end{tabular}




\section{DISCUSSION}

While immediate implant placement is a predictable treatment option, surrounding anatomical structures may increase the risk of complications such as nerve injury and lingual perforation in the attempt to achieve a successful immediate implant placement (Ortega-Martinez et al. 2012). In this study of 411 teeth, with equal number of all three study teeth, immediate implant replacing mandibular canines showed the lowest risk $(23.4 \%)$ of nerve injury, followed by $45.3 \%$ for mandibular first premolars and $79.6 \%$ for mandibular second premolars. The risk of nerve injury at mandibular second premolars as reported by Chrcanovic et al. (2016), Froum et al. (2011), and Lin et al. (2014) was 76.7, 65.0, and 49.4\%, respectively (Chrcanovic et al. 2016; Froum et al. 2011; Lin et al. 2014). The higher risk seen in this study was due to a shorter mean root apex to nerve canal distance which could be attributed to anatomical variations in different populations. To the best of our knowledge, this is the first study that included mandibular first premolars and mandibular canines.

To determine the root apex to nerve canal distance, two horizontal tangential lines were drawn, one line over the tip root apex and another line over the superior border of the nerve canal. Distance between these two lines was recorded as the root apex to nerve canal distance. This method of measurement maybe more representative and accurate compared to point-to-point measurement used in previous studies (Chrcanovic et al. 2016; Froum et al. 2011) especially when nerve canals were not located directly apical to the root apices. As a result, root apex to nerve canal distance may increase and provide a false information on the safe distance for immediate implant placement. In this study, the mean distance from root apices of mandibular canines, mandibular first and second premolars averaged at 4.10, 5.12 and $4.24 \mathrm{~mm}$, respectively, which is less than the recommended $6 \mathrm{~mm}$ safe distance. However, the standard deviation for the mean distances of all study teeth was $2.5 \mathrm{~mm}$ on average. Therefore, it is very prudent to assess the risk of nerve injury in each case individually. Despite the mean distances for all the study teeth on the right side of mandible were shorter than the left, the difference was not significant. This finding concurred with that of Chrcanovic et al. (2016).

A minimum root apex to canal distance of $6 \mathrm{~mm}$ was considered safe for immediate implant placement. This safe distance comprised of $4 \mathrm{~mm}$ of apical bone which is necessary for good primary stability and another $2 \mathrm{~mm}$ as a safe implant to nerve distance (Froum et al. 2011; Lin et al. 2014). To achieve good primary stability, Schwartz-Arad and Chaushu (1997) suggested that implants must be placed 3 to $5 \mathrm{~mm}$ apical to the socket. In their review, Greenstein and Tarnow (2006) suggested a safe distance of minimum $2 \mathrm{~mm}$ from implant to nerve. To be more cautious, Renton (2010) stated a minimum distance of $4 \mathrm{~mm}$. Her rationale was some drills used for osteotomy can be up to $1.5 \mathrm{~mm}$ longer than the planned implant, therefore, the need to increase the safe distance to avoid nerve injury during drilling. Thus, it is very important for dental surgeons to know the features of their implant drills to help in their treatment planning and surgery.

Aside from the 3 previously reported types of alveolar morphology (Chan et al. 2011b), namely convergent (C type), parallel (P type) and undercut (U type), we also observed sickle (S) type morphology. Sickle type morphology was mainly observed in mandibular canine regions. As a result of the proclination of mandibular canines, the alveolar bones in this region appeared crescent-shaped. Buccal perforations were mostly seen in this type of bone. Compared to lingual perforations, buccal perforations are easily visible and can be managed by bone grafting. The incidence of types of alveolar morphology at second premolar in this study varied from previous studies. Previous studies showed higher incidence of $\mathrm{C}$ type and $\mathrm{U}$ type but lower in $\mathrm{P}$ type compared to our study (Huang et al. 2015). These differences may be contributed by the different ethnicities and races as both previous studies were conducted in Taiwan which comprises mainly of Chinese (Mongoloid) while our study was conducted in Malaysia which made up of mainly Malays (Mongoloid), Chinese (Mongoloid) and Indians (Caucasoid) (Huang et al. 2015). Despite these differences, current and previous studies showed the most commonly observed alveolar morphology was $\mathrm{P}$ type followed by $\mathrm{C}$ type and $U$ type.

Placement of immediate implant may result in lingual plate perforation which is greatly dependent on the diameter of the implant as well as the alveolar bone morphology. Diameter of virtual implants used was not standardized in the assessment of lingual plate perforation in previous studies. Huang et al. (2015) found $1.2 \%$ of second premolar implants showed lingual perforation when $4.3 \mathrm{~mm}$ diameter implants were used. In another study by Chan et al. (2011a), risk of lingual perforation at mandibular second premolar was 1.1 and $1.2 \%$ when 4.0 and $5.0 \mathrm{~mm}$ diameter implants were used respectively. In our study, risk of lingual perforation ranged from $0.7 \%$ to $1.5 \%$ depending on diameter of implants used and alveolar bone morphology. Risk of lingual perforation increased with the increment of implant diameter. This concurred with those reported in previous studies (Chan et al. 2011a; Huang et al. 2015). While previous studies showed highest incidence of 
lingual perforation in $U$ type bone, we found the risk was highest in P type bone. This may be attributed to the lower incidence of $U$ type bone in this study. All perforations in $\mathrm{P}$ type bone in this study were associated with thin buccolingual width of the alveolar bone.

Sequelae of lingual plate perforation depend on the anatomical structures that are affected by the perforation. Branches of lingual artery and submental artery are near to anterior mandible. Any lingual perforation in the area may result in sublingual hemorrhage. If severe, airway can be compromised, and this can be fatal (Kusum et al. 2015; Mardinger et al. 2007). On the other hand, submandibular glands and lingual nerves are located near to lingual plate of posterior mandible. Lingual nerve is at risk of injury when perforation occurs above mylohyoid ridge (Greenstein et al. 2008). If perforation gone unnoticed, the extruded implant may cause inflammation of surrounding tissue or even infection (Greenstein et al. 2008). Therefore, it is recommended to palpate the lingual aspect of mandible before and after surgery to identify the presence of lingual concavity pre-operatively and for any implant extrusion post operatively. To minimize the risk of perforation, practitioners can either change the types of implants used or modify their surgical techniques. Chrcanovic et al. (2016) suggested to use shorter and wider implants while Chan et al. (2011b) used tapered instead of parallel implants. Implants position can be angulated to avoid undesirable lingual bone morphology. Besides manipulating the implant, in extraction sockets that are not dimensionally optimum to receive an immediate implant, the socket can be grafted and allowed to heal, followed by delayed implant placement (Iasella et al. 2003; Poulias et al. 2013). Socket grafting with delayed implant placement has also been reported to have lower risk of implant failure compared to immediate implant placement (Canellas et al. 2019).

According to a review in 2010 , mental foramina were located between first premolar and first molar, predominantly at the apex of mandibular second premolar followed by between apices of both premolars (Juodzbalys et al. 2010). Therefore, nerve present at the apex of first premolar can either be mandibular incisive nerve or inferior alveolar nerve depending on the position of the mental foramen. In contrary, nerve that is present mesial to first premolar is mandibular incisive nerve. In our study, we were able to detect $28.5 \%$ of mandibular incisive canal. Although this finding was similar to the one reported by Mardinger et al. (2007) in their cadaveric study, it differs greatly from the findings by
Pires et al. (2012) and Uchida et al. (2009) in their cone beam computed tomography (CBCT) studies. The former reported presence of mandibular incisive nerve in $100 \%$ of their sample while the latter reported $83 \%$. This vast difference could be due to different ethnicities as the previous studies were conducted in Japan and Ohio, respectively. Different images quality may affect identification of nerve canal, especially mandibular incisive nerve canal which can be as small as $0.5 \mathrm{~mm}$ in diameter (Uchida et al. 2009), as previous studies used CBCT machines with higher milliamperage which produced better quality images. Inability to locate nerve canal may be due to loss of cortication which can occur with age(Dora et al. 2016). Since age factor was not taken into consideration in the selection criteria, possibility of including CBCTs of patients of advanced age cannot be ruled out.

While most previous studies used only one diameter of virtual implant, our study compared implants of a few sizes that could possibly be placed at the study site. This enabled us to relate the effect of increment of implant sizes and risk of lingual perforation. Limitations of this study include relatively smaller sample size compared to some of the previous studies. Besides that, virtual implants used in this study were of parallel root-form which may not truly represent some of the implants available in the market. Some implants in the market were of tapered end. This means the risk of lingual perforation might be lower than that reported in this study if tapered implants are used. Besides that, implants can be angulated slightly in actual clinical situation to avoid lingual perforation (Wang et al. 2019). However, in this study, a standardized virtual implant position was used to ensure its reproducibility.

\section{CONCLUSION}

In conclusion, the risk of nerve injury was considerably high, with the highest risk involving immediate implantation at mandibular second premolars, followed by first premolars and canines. This observation was largely due to the inadequate root apex to nerve canal distance. On the other hand, the risk of lingual perforation was low due to different incidence of alveolar morphology observed compared to previous studies. This risk may be even lower in actual clinical cases if different implant designs and angulations were used.

\section{REFERENCES}

Canellas, J.V.D.S., Medeiros, P.J.D., Figueredo, C.M.D.S., Fischer, R.G. \& Ritto, F.G. 2019. Which is the best choice after tooth extraction, immediate implant placement or 
delayed placement with alveolar ridge preservation? A systematic review and meta-analysis. Journal of CranioMaxillofacial Surgery 47(11): 1793-1802.

Chan, H.L., Benavides, E., Yeh, C.Y., Fu, J.H., Rudek, I.E. \& Wang, H.L. 2011a. Risk assessment of lingual plate perforation in posterior mandibular region: A virtual implant placement study using cone-beam computed tomography. Journal of Periodontology 82(1): 129-135.

Chan, H.L., Brooks, S.L., Fu, J.H., Yeh, C.Y., Rudek, I. \& Wang, H.L. 2011b. Cross-sectional analysis of the mandibular lingual concavity using cone beam computed tomography. Clinical Oral Implants Research 22(2): 201206.

Chen, S.T. \& Buser, D. 2009. Clinical and esthetic outcomes of implants placed in post extraction sites. The International Journal of Oral \& Maxillofacial Implants 24(Suppl): 186217.

Chen, Z., Chen, D., Tang, L. \& Wang, F. 2015. Relationship between the position of the mental foramen and the anterior loop of the inferior alveolar nerve as determined by cone beam computed tomography combined with mimics. Journal of Computer Assisted Tomography 39(1): 86-93.

Chrcanovic, B.R., de Carvalho Machado, V. \& Gjelvold, B. 2016. Immediate implant placement in the posterior mandible: A cone beam computed tomography study. Quintessence International 47(6): 505-514.

Dora, A.C., Karjodkar, F., Sansare, K., Bansal, L., Ali, I., Motghare, D., Mishra, I., Kapoor, R. \& Tambawala, S. 2016. Decortication of inferior alveolar canal in elderly population: A cone beam computed tomography study. International Journal of Health Sciences and Research 6(9): 239-244.

Froum, S., Casanova, L., Byrne, S. \& Cho, S.C. 2011. Risk assessment before extraction for immediate implant placement in the posterior mandible. Journal of Periodontology 82(3): 395-402.

Greenstein, G. \& Tarnow, D. 2006. The mental foramen and nerve: Clinical and anatomical factors related to dental implant placement: A literature review. Journal of Periodontology 77(12): 1933-1943.

Greenstein, G., Cavallaro, J., Romanos, G. \& Tarnow, D. 2008. Clinical recommendations for avoiding and managing surgical complications associated with implant dentistry: A review. Journal of Periodontology 79(8): 1317-1329.

Huang, R.Y., Cochran, D.L., Cheng, W.C., Lin, M.H., Fan, W.H., Sung, C.E., Mau, L.P., Huang, P.H. \& Shieh, Y.S. 2015. Risk of lingual plate perforation for virtual immediate implant placement in the posterior mandible. A computer simulation study. Journal of the American Dental Association 146(10): 735-742.

Iasella, J.M., Greenwell, H., Miller, R.L., Hill, M., Drisko, C., Bohra, A.A. \& Scheetz, J.P. 2003. Ridge preservation with freeze-dried bone allograft and a collagen membrane compared to extraction alone for implant site development: A clinical and histologic study in humans. Journal of Periodontology 74(7): 990-999.
Juan del, V.L., Grageda, E. \& Gómez Crespo, S. 2016. Anterior loop of the inferior alveolar nerve: Averages and prevalence based on CT scans. Journal of Prosthetic Dentistry 115(2): 156-160.

Juodzbalys, G., Wang, H.L. \& Sabalys, G. 2010. Anatomy of mandibular structures. Part II: Mandibular incisive canal, mental foramen and associated neurovascular bundles in relation with dental implantology. Journal of Oral \& Maxillofacial Research 1(1): e3.

Kusum, C.K., Mody, P.V., Indrajeet, Nooji, D., Rao, S.K. \& Wankhade, B.G. 2015. Interforaminal haemorrhage during anterior mandibular implant placement: An overview. Dental Research Journal 12(4): 291-300.

Lazzara, R.J. 1989. Immediate implant placement into extraction sites: Surgical and restorative advantages. International Journal of Periodontics \& Restorative Dentistry 9(5): 333-343.

Lin, M.H., Mau, L.P., Cochran, D.L., Shieh, Y.S., Huang, P.H. \& Huang, R.Y. 2014. Risk assessment of inferior alveolar nerve injury for immediate implant placement in the posterior mandible: A virtual implant placement study. Journal of Dentistry 42(3): 263-270.

Mardinger, O., Manor, Y., Mijiritsky, E. \& Hirshberg, A. 2007. Lingual perimandibular vessels associated with life-threatening bleeding: An anatomic study. The International Journal of Oral \& Maxillofacial Implants 22(1): 127-131.

Ortega-Martinez, J., Perez-Pascual, T., Mareque-Bueno, S., Hernandez- Alfaro, F. \& Ferres-Padro, E. 2012. Immediate implants following tooth extraction. A systematic review. Medicina Oral Patologia Oral y Cirugia Bucal 17(2): e251-e261.

Pires, C.A., Bissada, N.F., Becker, J.J., Kanawati, A. \& Landers, M.A. 2012. Mandibular incisive canal: Cone beam computed tomography. Clinical Implant Dentistry and Related Research 14(1): 67-73.

Poulias, E., Greenwell, H., Hill, M., Morton, D., Vidal, R., Shumway, B. \& Peterson, T.L. 2013. Ridge preservation comparing socket allograft alone to socket allograft plus facial overlay xenograft: A clinical and histologic study in humans. Journal of Periodontology 84(11): 1567-1575.

Renton, T. 2010. Prevention of iatrogenic inferior alveolar nerve injuries in relation to dental procedures. Dental Update 37(6): 350-363.

Schwartz-Arad, D. \& Chaushu, G. 1997. The ways and wherefores of immediate placement of implant into fresh extraction sites: A literature review. Journal of Periodontology 68(10): 915-923.

Uchida, Y., Noguchi, N., Goto, M., Yamashita, Y., Hanihara, T., Takamori, H., Sato, I., Kawi, T. \& Yosue, T. 2009. Measurement of anterior loop length for the mandibular canal and diameter of the mandibular incisive canal to avoid nerve damage when installing endosseous implants in the interforaminal region: A second attempt introducing cone beam computed tomography. Journal of Oral and Maxillofacial Surgery 67(4): 744-750. 
Wang, T.Y., Kuo, P.J., Fu, E., Kuo, H.Y., Chang, N.N.S., Fu, M.W., Shen, E.C. \& Chiu, H.C. 2019. Risks of angled implant placement on posterior mandible buccal/lingual plate perforation: A virtual immediate implant placement study using CBCT. Journal of Dental Sciences 14(3): 234240.

Department of Oral and Maxillofacial Clinical Sciences Faculty of Dentistry

University of Malaya

50603 Kuala Lumpur, Federal Territory

Malaysia
*Corresponding author; email: daniel_khlim@um.edu.my

Received: 17 Mac 2020

Accepted: 6 September 2020 